\title{
Communicative Interaction in Language Learning Tasks among EFL Learners
}

\author{
Mohammad Sadegh Bagheri \\ Department of Foreign Languages, Shiraz Branch, Islamic Azad University, Shiraz, Iran \\ Forough Rahimi \\ Department of Foreign Languages, Shiraz Branch, Islamic Azad University, Shiraz, Iran \\ Email: rahimi.forough@yahoo.com \\ Mohammad Javad Riasati \\ Department of Foreign Languages, Shiraz Branch, Islamic Azad University, Shiraz, Iran
}

\begin{abstract}
This paper explores peer-peer interactions of low proficiency level children using a spot-thedifferences task in an EFL context in a language institute in Shiraz, Iran. The children were asked to practice with several sets of similar spot-the-differences tasks and the analysis focuses on the observable changes from the first to the last repetition. After the task performances were recorded, the children were invited to watch their first and last performances and comment on the changes they noticed in an interview. Both the analysis of their dialogues performing the tasks and their reflections clearly indicate that peer-peer interactions with this age group at a very low level of competence can bring various benefits and thus primary language teachers could consider introducing similar communication tasks with children with some confidence.
\end{abstract}

Index Terms - peer-peer interaction, communicative tasks, communicative interaction, EFL learners

\section{INTRODUCTION}

Language learning tasks have been explored with adult language learners (Ellis, 2003; Skehan, 2003; Nunan, 2004; Edward and Willis, 2005) but studies with children have been scarce even though learning English has seen a dramatic expansion to the primary sector in many contexts around the world (Kubanek, 1998; Cameron, 2003). This study attempts to explore children's ability to interact with each other in English as a foreign language at a very basic level of competence, using a popular communication task, 'spot the differences'. A series of repeated performances with the same type of task is explored to find out what gains this type of task repetition may bring. The study was motivated by the observation in many primary school contexts that the majority of language practices that learners receive tend to be centered around pattern practice, drilling and memorizing prefabricated expressions rather than experimenting with fluency tasks to express their own meanings in a less restricted manner (Mitchell and Lee, 2003). Teachers often feel that children at a low level of competence are generally unable to handle communication tasks and benefit from them in any way.

\section{BACKGROUND}

\section{A. Language Tasks and Repetition}

Tasks encourage learners to communicate with each other in real time. Due to the immediate pressures of spontaneous communication in tasks, learners have to simultaneously focus on both form and meaning. Since humans' processing capacity is limited (Anderson, 1995) and meaning is prioritized over form (Van Patten, 1990), manipulating learners' attention to focus on linguistic forms has become a key priority in research. Repetition is a task performance condition that can manipulate learners' attention through freeing up processing resource capacities. Bygate's work in the last decade has shown that in monologic tasks, repetition involves a special type of rehearsal where the learners can relate the repeated performance 'to information kept in the long term memory store' (Bygate, 2001). When they have the chance to repeat a task, learners can shift their attention to produce more complex grammar, more appropriate vocabulary, and they can generally organize and optimize their language resources more effectively (Gas et al, 1991; Bygate and Samuda, 2005). When learners are exposed to interactive tasks, they can rely on their previous performances of the same task to a limited extent only since their interlocutor's contributions will always bring some novelty to the joint interaction. Interactive task solutions are co-constructed and speakers need to satisfy their interlocutors' needs in addition to monitoring their own performance.

Some studies with adult learners have explored the effects of repeating interactive tasks (Plough and Gass, 1993; Platt and Brooks, 1994; Brooks et al., 1997; Lynch and Maclean, 2000, 2001). Plough and Gass (1993) conducted a study using two tasks, a type of spot-the-differences task and a discussion task and found that students who repeated 
them used more confirmation checks to negotiate meaning with each other. Lynch and Maclean (2001) conducted a study which incorporated the repetition of a complex poster carousel task. This study involved mature adults learners of English in a medical ESP class. The students had to prepare a poster, display it and act as hosts answering questions of fellow students about it. The repetition of the tasks involved the hosts of the posters in explaining their messages to different people with different questions. Lynch and Maclean found that after six repetitions their students' language improved in many ways. All students produced more fluent and more accurate language, they all improved their phonology and vocabulary (both access and selection) and many of them improved their syntax, too. The subjects' ability to reflect on the changes was related to their proficiency level in English. The higher proficiency learners were better able to reflect on the changes brought about by the repetition of the task. With beginner-level students learning Spanish, two studies by Platt and Brooks (1994) and Brooks et al. (1997) showed that task repetition even at lower levels of competence led to students being able to gain better control of the tasks by using less L1 and less overt statements of self-regulation.

\section{B. Children's Peer-peer Interactions}

One important aspect of interactions in tasks is the need to collaborate effectively with a partner and this requires an appreciation of the partner's needs. Children's overall ability to take their partner's needs in peer-peer interactions grows with age (Azmitia, 1998). Research in L1 development indicates that different age groups learn to cope with demands needed for peer-peer interactions gradually as they mature (Nelson, 1996; Ricard, 1993; Meadows, 1998; Woods, 1998; Anderson and Lynch, 1988). Young children often rely on adults to manage conversations for them (Scakella and Higa, 1981). In the absence of the adult partner, when they are communicating with other children, they show weaknesses both as speakers and as listeners. As speakers they have difficulty in constructing unambiguous messages and as listeners they can't judge the adequacy of incoming messages (Lloyd et al. 1984; Robinson and Robinson, 1984). The ability to take full responsibility for ones' own utterances as well as understanding partners' utterances are skills gradually increasing with age. All these developmental findings influence interaction in second or foreign languages and research in child second language learning clearly reflect these developmental influences. Studies involving child subjects working in pairs with other children or with adults have been carried out in different contexts (Oliver, 1988, 2000, 2002; Mackey et al., 2003; Ellis, 1985) and these studies have investigated various interactional processes, such as giving and utilizing feedback, question formation and meaning negotiation. The results indicate that children benefit from interacting with both peers and adults and with both NS and NNS interlocutors but both learner age and interlocutor type are important variables. Mackey and Silver (2005) claim that SLA research finding should not be generalized to children without adequate empirical evidence. However, little is known about peer-peer interactions of different age groups especially in EFL contexts, that is, what children can cope with and benefit from.

\section{OBJECTIVES}

This study aims to explore EFL children's peer-peer interaction using a spot-the-differences task. Thus, main aim of the study is to identify what benefits the repetition brings, if any and whether the children are aware of these benefits.

\section{DESIGN OF THE STUDY}

\section{A. Participants}

The children were selected from beginner levels, with almost low level of proficiency in a language institute in Shiraz, Iran. The sample was chosen among a population who has learned English as a foreign language in a traditional teaching context, that is, English classes closely following the course book, emphasizing the grammar, rehearsal of set dialogues and memorizing through rote learning.

These children had never seen or used interactive tasks in their English lessons before and they never had the opportunity to use their English spontaneously without preparation or rehearsal.

\section{B. Data Collection}

For each recording a different version of the spot-the-differences task was used. The task is clearly meaning-focused, conforming to Skehan's (1998) definition. According to this definition, in tasks meaning is primary and there is always some communication problem to solve. Tasks also mirror comparable real-world activities and task completion has priority over other performance outcomes. In the spot-the differences task each picture represents a scene of a playground which is consisted of different objects, people doing thing, animals, etc.

For each recording a variation from set to set was achieved by a random organization of the content items within the same scenes. The following types of differences were used:

- Type 1: In picture A, a particular item was present but it was missing in picture B.

- Type 2: The number of a particular item in picture A was different from B.

- Type 3: A particular item in picture A was replaced by something else in picture B, or the same person was doing something different in each picture. 
The children were told that the researcher is interested in how the tasks would work with children who are learning English. It was clearly stated that their performances and opinions were only available to the researcher and they were not going to count towards their assessment at final. An informal briefing session was organized to show a sample set of the task to the children but no advice was given to them as to how to manage the tasks, how to help each other or what the best strategies would be to locate the differences. They were invited to do the task in their mother tongue in order for them to familiarize themselves with the task and get a feel for how it works. Then they were recorded three times in English over a period of three weeks.

The recordings took place in a small empty classroom in the institute but outside the children's English classes with only the researcher in the room, who needed to get to know the children prior to the study. The researcher did not interfere at all and the children were in control as to when to stop the video-recorder.

\section{DATA ANALYSis}

The children's performances were transcribed and changes between the different repetitions were analyzed, to see the most obvious change between the first and the last recording in English, and to evaluate the children's fluency on the task. In this paper, however, we focused on another aspect of their interaction. It seems that the opportunity to repeat the task helps them to appreciate each other's needs better in view of the demands of the task. In particular we looked at peer assistance and their ability to pay attention to each other's utterances. Finally, we also discussed the extent to which they were aware of the benefits observable in their interactions.

\section{A. Peer Assistance}

Given that children at this age (the participants were mainly from 12-14 age group) are still developing their skills as speaking partners, it was of particular interest to examine to what extent they appreciate their conversational partner's needs and whether their ability to do this is going to be affected by the task repetition. Adult studies have demonstrated that peer assistance can lead to learners using more target-like grammar in interactive tasks (Donato, 1994; Ohta, 2000). We also assumed that there is evidence of this in this experiment, that is, the weaker learners develop the target structure for describing people or things across the repetitions of the task with his/her friend's assistance.

\section{B. Paying Attention to Each Other's Utterances}

The opportunities to repeat the spot-the-differences task led to changes in the way the children paid attention to each other's utterances and to the demands of the task at hand. At the beginning they considered the spot-the-differences task to be an opportunity to display their own knowledge almost irrespective of what their partners had to say. By the end, it was obvious that their interpretation had moved on from 'an individual task' to 'a joint game' and they had learnt to take notice and build on each other's utterances.

One basic characteristic feature of referential gap tasks, such as the spot-the- differences task, is that all participants need to pay attention to what their partners are saying because it is only by building up joint information that they can find and keep tally of the differences.

\section{Children's Comments}

After recording the tasks, the children were invited together for an interview with the researcher to talk about the tasks and the benefits of repetition as they perceived them. The children watched their first and last performances and commented on the differences they noticed. They were asked if they feel more confident and relaxed using their English, if they can explain their messages better and if they have learnt from each other's ways of speaking, and if they have learnt new thing like new words. They had noticed their initial lack of fluency and general hesitation. Their comments showed that in the first performance they were more concerned with their own utterances and they were saying what they could rather than paying attention to each other.

Next, they explained why they felt they were struggling at the beginning. They said that the difficulty lay in their lack of familiarity with the task. The other reason that they mentioned was the lack of words needed to describe items in the pictures. Their concern with vocabulary was clearly evident in the performances in that many of their attempts to assist each other described earlier were related to vocabulary. This concern was clearly articulated in their reflections too.

Their comments indicated their growing awareness to pay attention to what the partner was saying in order to meet the challenges of the task. The children clearly enjoyed the task and seeing the improvements between the performances gave them a real sense of satisfaction.

\section{DISCUSSION}

The task repetition clearly led to many gains for the children. They enjoyed the experience of speaking English in a spontaneous manner with each other, managed to complete the task by the last repetition more fluently. They assisted each other across the repetitions but in particular the more competent learner assisted the weaker one in many different ways. In addition, the children improved their grasp of the task and could better appreciate what the task demands were. They learnt to pay attention and respond to each other more carefully. On the first occasion they handled the task as one that requires each speaker to simply display their knowledge of English irrespective of the partner's contributions and 
later they turned the task into a joint fast-moving game that they tackled with confidence. The interview indicated that they were able to see the benefits of the task repetition and were aware of many of the positive changes that occurred in their performances.

All this evidence suggests that using this kind of task repetition with communication tasks can work effectively with children at low levels of proficiency. In addition, it may be the case that this kind of task repetition (i.e. practicing with the same task type) can provide a scaffold that children can benefit from without or before the intervention from the teacher. Through a series of task repetition these children moved from less effective to more effective ways of handling both this gap task and each other as conversational partners. Interacting with a peer on repeated occasions can be a rich learning experience and working with the same partner over several repetitions means children can grow more confidence. In classrooms this can be a fruitful way of introducing tasks: getting children to practice with the same partner and then to think about what they did and why and how they improved.

It is of course not possible to claim that all the changes happened as a result of the task repetition exclusively. The task performances and the follow-up interview were recorded over a period of three weeks and even though the children were not encouraged to do any preparation or consultation with anybody, it would have been unnatural for them not to mention their experiences to anyone and above all not to talk about it between them. It is quite likely that the children talked about the tasks to their parents, friends, siblings or teachers. They may also have looked at their English textbooks, dictionaries or other sources to find words such as names of rooms or names of animals.

This study did not attempt to set up a direct cause and effect relationship between repetition and learning in an experimental manner because many of the variables were not controlled. Instead, the claim is that repetition offered regular opportunities and a vehicle for the children to display their growing ability to interact with each other and control a specific type of task without any intervention from the teacher. Assisting each other promptly, paying attention to each other or realizing that they had to tighten the search for differences could not have been improved in any other way outside the task but by directly participating in the task on repeated occasions.

\section{CONCLUSION}

This study supports earlier research by suggesting that it is important to provide practice in task repetition. The analysis of the data illustrates that repetition of this kind can be beneficial at low levels of proficiency with children, not just adults. These encouraging results may suggest that teachers with beginner-level child learners can be more confident that peer-peer interactions, at least for this age group, offer multiple benefits to learners and practicing with similar tasks is an effective way of encouraging these positive changes to take place. It is of course important to add that different age groups need different task types and younger children are less likely to notice the demands of the task or the needs of the interlocutor.

There are naturally limitations to the tentative claims made in this paper. Limitations include the choice of one specific task and a specific teaching/learning and cultural context. Research with different tasks, more learners in different contexts and of different age groups would be essential to begin to build up a picture about the processes that occur in children's peer-peer interactions in language tasks.

\section{REFERENCES}

[1] Anderson, J. (1995). Learning and memory: An integrated approach. Wiley Press.

[2] Anderson, A. and Lynch, T. (1988). Listening. Oxford University Press.

[3] Azmitia, M. (1988). Peer interaction and problem solving: Where are two heads better than one? Child Development 59, 87-96.

[4] Brooks, F. B., Donato, R. and McGlone, J. V. (1997). When are they going to say it right? Foreign Language Annals 30, 52441.

[5] Bygate, M. (2001). Effects of task repetition on the structure and control of oral language. In Bygate, M., Skehan, P. and Swain, M., editors, Researching pedagogic tasks: second language learning, teaching and testing, Pearson Educational, 23-48.

[6] Bygate, M. and Samuda, V. (2005). Integrative planning through the use of task repetition. In Ellis, R., editor, Planning and task performance in second language, John Benjamins, 37-76.

[7] Cameron, L. (2003). Challenges for ELT from the expansion in teaching children. ELT Journal 7, 105-12.

[8] Donato, R. (1994). Collective scaffolding in second language learning. In Lantolf, J. and Appel, G., editors, Vygotskian approaches to second language research, Ablex, 33-56.

[9] Edwards, C. and Willis, J. (2005). Teachers exploring tasks in English language teaching. Palgrave Macmillan.

[10] Ellis, R. (1985). Teacher-pupil interaction in second language development. In Gass, S. and Madden, C., editors, Input in second language acquisition, Newbury House, 85-98.

[11] Ellis, R. (2003). Task-based language learning and teaching. Oxford: Oxford University Press.

[12] Gass, S., Mackey. A., Alvarez-Torres. M., and Fernandez-Garcia, M. (1999). The effects of task repetition on task linguistic output. Language Learning 49(4), 549-81.

[13] Kubanek, A. (1998). Primary foreign language teaching in Europe - trends and issues. State of the art survey article. Language Teaching 31, 193-205.

[14] Lloyd, P., Baker, E. and Dunn, J. (1984). Children's awareness of communication. In Feagans, L., Golinkoff, G. and Garvey, C., editors. The origins and growth of communication, Ablex.

[15] Lynch, T. and Maclean, J. (2000). Exploring the benefits of task repetition and recycling for classroom language learning. Language Teaching Research 4(3), 221-49. 
[16] Lynch, T. and Maclean, J. (2001). A case of exercising? Effects of immediate task repetition on learners' performance. In Bygate, M., Skehan, P. and Swain, M., editors, Researching pedagogic tasks: second language learning, teaching and testing, Pearson Education, 141-62.

[17] Mackey, A., Oliver. R, and Leeman, J. (2003). Interactional input and the incorporation of feedback: an exploration of NS-NNS and NNS-NNS adult and child dyads. Language Learning 53, 35-66.

[18] Mackey, A. and Silver, R. E. (2005). Interactional tasks and English L2 learning by immigrant children in Singapore. System 33 , 239-60.

[19] Meadows, S. (1998). The child as a thinker. Routledge.

[20] Mitchell, R. and Lee, J. (2003). Sameness and difference in classroom learning cultures: interpretations of communicative pedagogy in the UK and Korea. Language Teaching Research 7(1), 35-63.

[21] Nelson, K. (1996). Language in cognitive development. Cambridge: Cambridge University Press.

[22] Nunan, D. (2004). Task-based language learning. Cambridge: Cambridge University Press.

[23] Ohta, A.S. (2000). Rethinking interaction in SLA: developmentally appropriate assistance in the zone of proximal development and the acquisition of grammar. In Lantolf, J., editor, Sociocultural theory and second language learning, Oxford University Press, 51-78.

[24] Oliver, R. (1998). Negotiation of meaning in child interactions. The Modern Language Journal 82(3), 372-86.

[25] Oliver, R. (2000). Age differences in negotiation and feedback in classroom and pairwork. Language Learning 50, $119-51$.

[26] Oliver, R. (2002). The patterns of negotiations of meaning in child interaction. Modern Language Journal 86, 97-111.

[27] Platt, E. and Brooks, F. (1994). The acquisition rich environment revisited. Modern Language Journal 78, 497-511.

[28] Plough, I. and Gass, S. (1993). Interlocutor familiarity: effects on interactional structure. In Crookes, G. and Gass, S., editors, Tasks and language learning: integrated theory and practice, Multilingual Matters, 35-56.

[29] Ricard, R. (1993). Conversational coordination: collaboration for effective communication. Applied Psycholinguistics 14, 387412.

[30] Robinson, E. J. and Robinson, W. P. (1983). Children's uncertainty about the interpretation of ambiguous messages, meanings and reality. British Journal of Developmental Psychology 36, 305-20.

[31] Scarcella, R.C. and Higa, C. (1981). Input, negotiation and age differences in second language acquisition. Language Learning 31, 409-32.

[32] Skehan, P. (1998). A cognitive approach to language learning. Oxford University Press.

[33] Skehan, P. (2003). Tasks in L2 learning and teaching. Language Teaching 36(1), 1-14.

[34] Van Patten, B. (1990). Attending to content and form in input: an experiment in consciousness. Studies in Second Language Acquisition. 12, 287-301.

[35] Wood, D. (1998). How children think and learn. Blackwell.

Mohammad Sadegh Bagheri is an assistant professor of TEFL (Teaching English as a Foreign Language) and a faculty member at Islamic Azad University, Shiraz branch. He has published many books and articles, and presented at several national and international conferences. His main areas of interest are second language teaching/acquisition and teacher education.

Forough Rahimi is a $\mathrm{PhD}$ candidate of TEFL (Teaching English as a Foreign Language) at Islamic Azad University, Shiraz branch, where she presently teaches. She has published some books and articles, and presented at several national and international conferences. Her areas of interest are second language teaching/acquisition, teacher education and critical applied linguistics.

Mohammad Javad Riasati is a PhD student of TESL (Teaching English as a Second Language) at University Putra Malaysia. He has been teaching at different language institutes and universities. His areas of interest are foreign/second language acquisition and teaching. 